creases (for either or possibly both of the reasons already given) until the condensation takes place wholly on ions. For greater intensities of ionization the number of ions must increase further and hence the efficient nucleation rises again while the curve passes through a minimum.

The curves enable us to make certain interesting comparisons, inasmuch as the same nucleation results from radium decaying for a stated length of time, as results from the action of radium at a certain distance from the line of sight. From the importance of secondary radiation in connection with these observations, such comparisons are probably not simple. The essential feature is the passage of the nucleation through the same stages of variation, whether of size or of number, in both cases, no matter how the given successive intensities of ionization may be produced, or whether they come from within or without.

My thanks are due to Professor Barus for his suggestions and his assistance throughout the research.

Brown Universtty, Providence, R. I.

\section{A LACUSTRINE APHID.}

ONE would suppose that submerged aquatic plants might wholly escape the attacks of plant-lice and scale-insects. In the Feuille des Jeunes Naturalistes, February, 1905, p. 62, G. Goury describes a supposed scale-insect which he found on a submerged petiole of Limnanthemum near Fontainbleau, in France. Unhappily, he put it in an aquarium, and the pond-snails (Limnoca) devoured it during the night. This prevented him from giving a description, and although he names it Lecanium limnanthemi, we can not resist the observation that all he says about it would apply to a leech egg. However, it is possible for aquatic plants to be attacked by aphids, though these do not inhabit the wholly submerged parts. On October 7 of the present year, my wife and I visited a lake in the immediate vicinity of Boulder, Colorado. The shallow water contained a large quantity of Myriophyllum verticillatum. L., a submerged plant with only small portions projecting above the surface. We were astonished to find that whenever the plant was not wholly submerged it was infested by aphids, usually in enormous numbers. At first I wondered whether they could have come from the adjacent terrestrial vegetation; but an examination of the narrow-leafed cottonwoods (Popuhus) and cockleburs (Xanthium) near by did not reveal any aphids. Closer inspection showed that the insects were thoroughly at home on the Myriophyllum and were undergoing all their transformations thereon. We brought some home, fully believing that we had something new, but on looking up the literature it was found impossible to distinguish them from the European (and doubtless circumpolar) Rhopalosiphum nymphoce (L.), which is said by Buckton to infest water-lilies (to which it is at times very destructive), Alisma, Butomus, Potamogeton, Hydrocharis, Lemna, etc.

The following description, from the Colorado material, is given because the available descriptions are somewhat incomplete; it will also be useful in case any doubt should arise as to the absolute identity of the European and American forms.

Winged Form.--Yellowish-olive, with the head, the chitinous plates of the thorax and the antennæ black; the middle of the abdomen also suffused with black; legs black, pallid only at extreme base; wings clear, stigma very light-yellowish, nervures black; nectaries incrassate, with the apical part black, the basal pallid; lateral edges of abdominal segments with alternate light and dark spots, best seen in balsam mount; antennæ on frontal tubercles; third joint with several sensoria on outer side, fifth with a sensorium in a notch not far from apex; surface of joints finely imbricated. Measurements: length of body about $1_{\frac{1}{2}} \mathrm{~mm}$., of wing about $2 \frac{1}{2} \mathrm{~mm}$.; the rest in $\mu$-nectaries, 255; cauda narrow and fairly long, its width 37 ; anterior tarsus (excluding claws), 120; antennal joints, (3) 225 , (4) 165 , (5) 150 , (6a) 97 , (6b) 225. Wings with branched vein having distance from first branch to second, 620 ; second to tip of wing, 225 .

Apterous Form.-About $2 \mathrm{~mm}$. long, broad, 
beak reaching lower edge of middle coxæ. Yellowish-brown or yellowish-olive; an obscure dark suffusion down the middle of the abdomen; antennæ, legs and apical part of nectaries, blackish. A whitish waxy powder on under surface. The young are pale green or pale reddish. The pupæ have more of the bluish-white wax, and have a very distinct dark mark on the middle of the abdômen.

The insects swim well on the surface of the water.

T. D. A. Cockerell.

\section{THE NEW ORLEANS MEETING OF THE AMERICAN ASSOCIATION FOR THE ADVANCEMENT OF SCIENCE.}

THE permanent secretary announces that owing to delayed negotiations with the railroads with regard to rates and on account of a printers' strike in Washington, the publication of the preliminary announcement of the New Orleans meeting has unfortunately been delayed. It is probable, however, that the announcement will be mailed to all members of the association from Washington about December 8. Additional information to that contained in the announcement will be found in ScIence of December 15 and December 22.

As announced last week the Southeastern Passenger Association, including practically the territory south of the Potomac and Ohio Rivers and east of the Mississippi, has granted a one-fare round trip rate plus 25 cents, and the Central Passenger Association has now adopted the same rate. Other passenger associations will either adopt this rate or with the northern associations a one-fare and one third rate to their southern terminals, the one-fare rate holding for distances south of these terminals. The latter plan has been adopted by the Trunk Line Association, which includes New York, New Jersey, nearly all of Pennsylvania, Delaware, Maryland and West Virginia north of Charleston. This will make a very reasonable rate amounting to about $\$ 36$ from New York City and $\$ 27.75$ from Washington.

The plans for the meeting are practically completed and many interesting features will be announced in addition to those already mentioned in these columns. The social features will include a smoker at the Washington Artil- lery. Hall on Friday night, December 29; a general reception on the night of December 30, an excursion on December 31 to the large sugar plantations, receptions by private citizens of New Orleans, and personally conducted trolley rides over the city, particularly through the most interesting old and historic parts. Visits will also be arranged to the many industrial establishments and to the new municipal drainage plant.

The symposium to be held under the auspices of Section $\mathrm{K}$ on the subject of yellow fever and other insect-borne diseases is attracting much attention, and many prominent experts have accepted invitations to speak. Professor Farlow, the retiring president, has announced as his subject 'The Popular Conception of a Scientific Man at the Present Day.'

On Monday evening the American Chemical Society will hold it annual subscription dinner, and the visiting members of the Sigma Xi will also hold a dinner at a time and place to be announced later. The hotels have announced reasonable rates, and a full list of these rates, together with a list of boarding houses, will be printed in the preliminary announcement.

The permanent secretary reiterates the announcement on the authority of the best sanitarians in the country that there should not be the slightest fear in the mind of any member of the association that New Orleans will be an unhealthy place at the time of the meeting or that it is now unhealthy. In fact, the krilliant sanitary achievement of last summer in wiping out the yellow fever epidemic should greatly add to the interest of a visit to $\mathrm{New}$ Orleans at this time. This fact and the general interest attaching to this unique city, together with the unprecedentedly low railroad rates, should combine to bring about an especially large attendance and particularly from the north and east. A visit to New Orleans and its vicinity is in many ways as interesting as a visit to France or Spain.

\section{SCIENTIFIC NOTES AND NEWS.}

Dr. William M. L. Coplin, professor of pathology and bacteriology in Jefferson Med- 